\title{
Procuring Low-Energy Design and Consulting Services
}

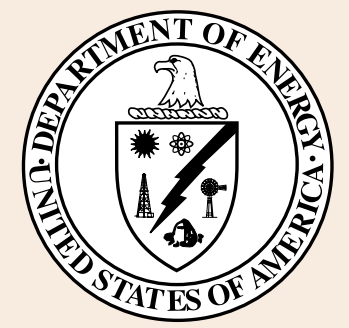

U.S. Department of Energy

Office of Energy Efficiency and Renewable Energy

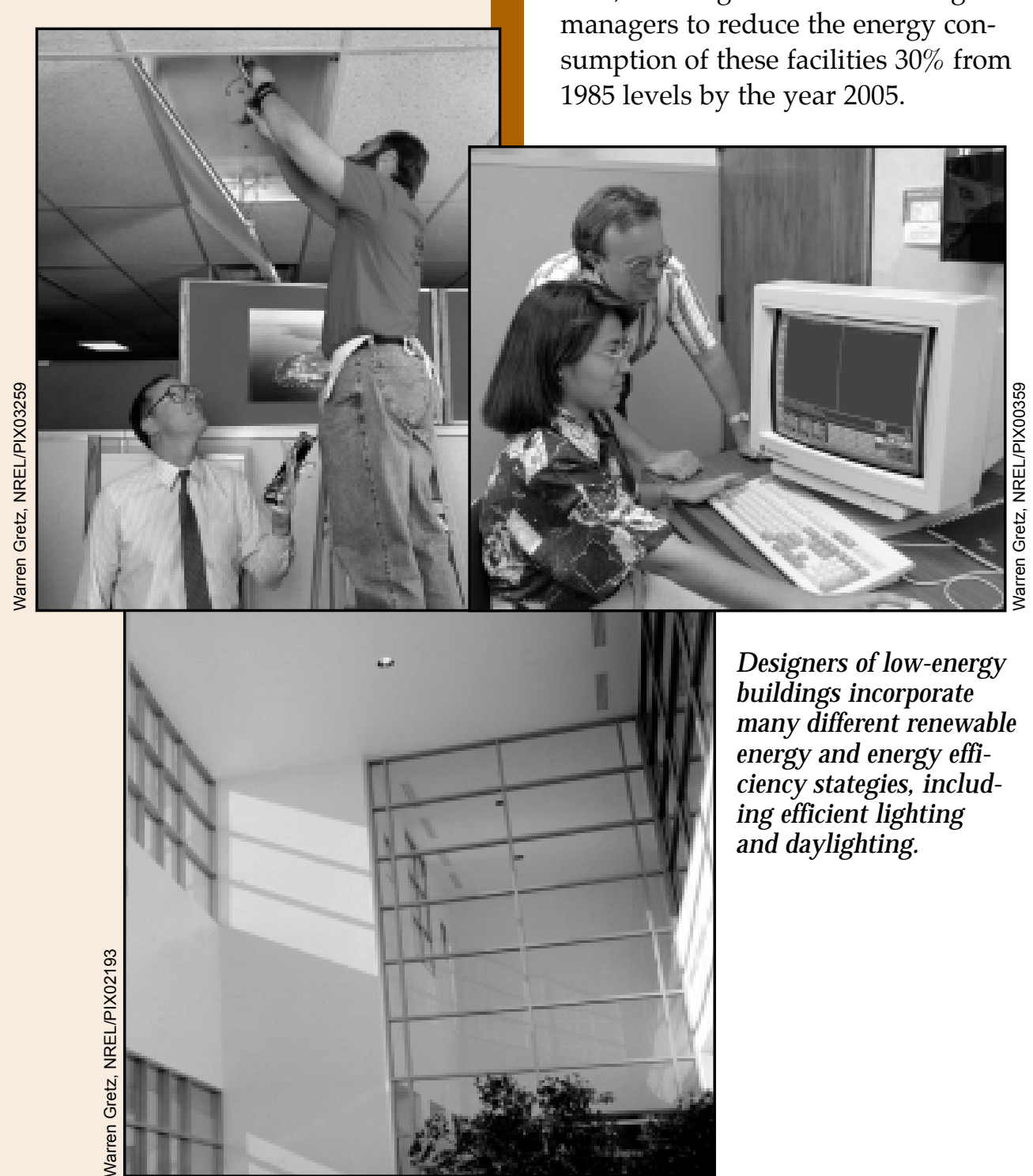
construct, renovate, and maintain thousands of offices, warehouses, and dwelling units in a wide range of climates and conditions. As the world's largest consumer of energy (1.2 quadrillion British thermal units [Btu] delivered to the point of use in fiscal year 1994), the Federal government has a tremendous opportunity to save vast amounts of money each year in energy costs. Executive Order 12902, which was passed in 1994, challenges Federal building managers to reduce the energy consumption of these facilities $30 \%$ from 1985 levels by the year 2005 .

A Guide for Federal Building Managers, Architects, and Engineers

Dozens of Federal agencies design, 
given here, you can optimize the use of energy resources in your new construction and renovation projects, saving U.S. taxpayers millions of dollars.

Achieving superior building energy performance requires a comprehensive effort that begins during programming; moves through the selection of architectural and engineering professionals; continues through schematics, design development, and construction documents; and culminates in building construction and commissioning. Superior building performance must then be sustained by conscientious maintenance and confirmed by monitoring.

Incorporating low-energy and climate-responsive strategies requires a unique perspective, that of wholebuilding performance. This means learning to balance heating, cooling, and lighting requirements using both energy efficiency and renewable energy. It also means understanding the interactive effect of architectural decisions such as orientation, the amount and location of glazing, and the placement of thermal mass and insulation on heating, cooling, and lighting.

If low-energy building design is so great, why isn't everybody using it? In part, because evaluating these complex trade-offs requires some type of analysis. The tools to evaluate these trade-offs used to be cumbersome and expensive. However, a new generation of software has made this process both easy and accurate. With the Federal Energy Management Program (FEMP) as an advocate and you as project champion, more buildings can benefit from low-energy design.

Project Manager ChecklistGetting Started

- Do members of the in-house project team understand what is meant by low-energy building design and whole-building performance?
- Is someone on the project team prepared to act as a "champion" for low-energy building design throughout design and construction?

- Are members of the project team committed to sustaining a focus on energy performance throughout all phases of the project?

\section{Programming}

\section{Establish Low-Energy Building Design as a Project Goal}

A critical first step of every project is to explicitly define goals. This is particularly true for building energy performance. A general goal for most Federal projects is to produce a beautiful, sustainable, cost-effective building that meets its program; encourages productivity; and consumes as little nonrenewable energy as possible through the use of passive solar design, energy efficiency, and other renewable resources. To the extent that the energy performance of a project can be clearly and quantitatively stated at the beginning of design and construction, the more likely it is to be factored into all decisions throughout the process.

Establishing energy performance goals can be difficult if your agency has task order contracts to develop building programs with architects and engineers that were selected because of expertise in specialties other than energy efficiency and passive solar design (such as life safety, seismic design, or accessibility). Consider writing very specific language into your new requests for proposals that stresses the need for indefinite-quantity contractors to demonstrate expertise in energy efficiency and the use of renewable energy sources in building design. Indicate that they will be responsible for developing specific energy consumption targets and that, if they do not have the expertise on staff, they must demonstrate the ability by hiring knowledgeable consultants to do the job. 


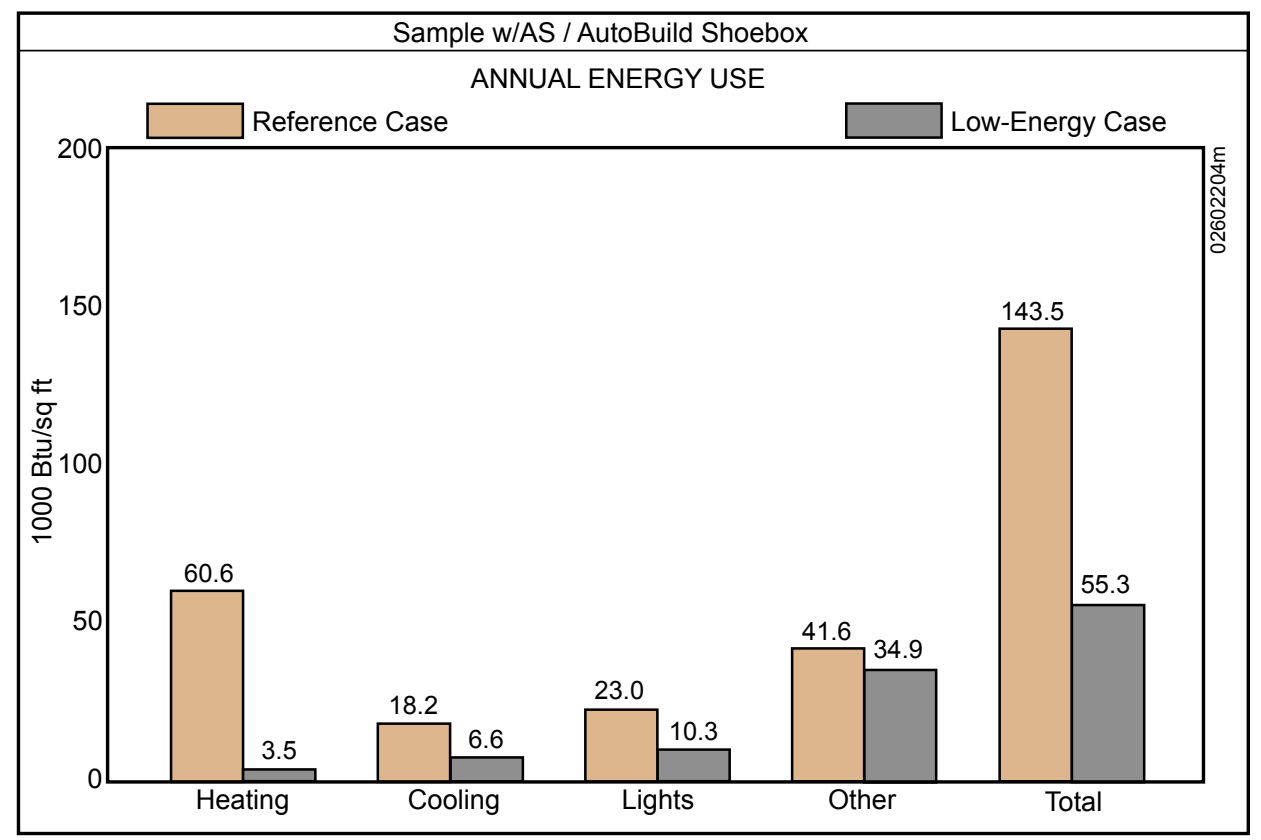

Figure 1. This sample ENERGY-10 "Autobuild" report is suitable for inclusion in programming documents to indicate energy performance targets.

\section{Use Appropriate Language}

Many Federal agencies, such as the General Services Administration (GSA) and the Department of Defense, already use appropriate language in their contracts to encourage the use of low-energy building design and renewables in all new construction and major renovations wherever technically and economically feasible. This language, however, often dates back to the late 1970s and early 1980s, and does not provide usable guidance or direction to contractors and other design professionals. Therefore, it is necessary to first review existing agency documents and determine how their directives can be used. For example, the GSA Prospectus Development Study (PDS) process clearly allows for energy and passive solar performance to be prominently called out as a fundamental design criteria, or what they call "functional objective," in the Building Systems Matrix that summarizes project goals.

\section{Define Energy Performance Targets}

What is meant by an energy target? It is a quantitative measure, or goal, of the maximum expected energy consumption for a structure based on accepted calculation procedures.

In smaller projects (projects of approximately 10,000 square feet $\left[\mathrm{ft}^{2}\right]$ or less with only one or two thermal zones, such as warehouses, small offices, or individual residences) use of quick, design-based, climate- and program-specific energy software such as ENERGY-10 or Building Design Advisor, during programming can be helpful. Using these software packages, Federal managers or their subcontractors can develop numerical energy targets, including breakdowns of estimated energy consumption for heating, cooling, and lighting, into their program documents. Incorporation of this kind of information in a program statement provides a criteria against which to evaluate subsequent design performance (see Figure 1).

For larger multizone projects such as laboratories or high-rise office buildings, it will be necessary to run more complex software packages such as DOE 2.1E, Blast, or the equivalent to generate similar estimates of energy consumption. Because this can be time consuming and expensive, as an alternative, national average energy consumption data by building type (available through the Energy Information Administration [EIA], part of the U.S. Department of Energy) can be referenced and cited as targets to be met or exceeded in the course of the project.

For example, according to the EIA, in 1995 the average office building in the United States consumed energy at the rate of $\$ 1.51$ per square foot.

Although actual energy consumption for any given office building can deviate significantly from this national mean because of a wide range of factors, including building size, local climate, mechanical system control strategies, utility rates, maintenance practices, and occupancy schedules, it does provide a useful point of reference. 
In new office design it is economically realistic to reduce energy costs from $30 \%$ to $50 \%$ below national averages if an optimum mix of lowenergy design strategies is applied to the building design. These strategies might include optimized glazing and insulation, daylighting, shading, and passive solar heating. Even greater savings are feasible when advanced technologies and techniques are employed.

This suggests that an annual savings of between $\$ 0.45$ and $\$ 0.75$ per square foot of office building is a reasonable estimate of the maximum cost savings possible from the use of energy-efficient design. However, if you compare energy consumption in your new design to a hypothetical "base-case" building (see p. 6) rather than to the national mean for existing structures, the possible savings will be more modest. In this instance, savings might be expected to range from $\$ 0.20$ to $\$ 0.30$ per square foot per year, depending critically on the definition of the base-case building.

\section{Energy Analysis Tools}

\section{BLAST*}

BLAST Support Office 1206 West Green Street Urbana, IL 61801

(217) 333-3977

\section{Building Design Advisor}

Energy and Environment Division

Lawrence Berkeley Laboratory

Berkeley, CA 94720

(510) 486-4000

Building Energy Simulation Group Energy and Environmental Division Lawrence Berkeley Laboratory

Berkeley, CA 94720

(510) 486-4000
Available from: kmp.1b1.gov/BDA

\section{DOE 2.2*}

Designing Low-Energy Buildings with ENERGY-10 Software Passive Solar Industries Council 1331 H Street, N.W., Suite 1000

Washington, DC 20005

(202) 628-7400

HAP (Hourly Analysis Program) Carrier Corporation

P.O. Box 4808

Syracuse, NY 13221

(315) 432-7072

www.carrier_commercial.com

\section{TRACE}

The Trane Company

3600 Pammel Creek Road

La Crosse, WI 54601-7599

(608) 787-3926
* A new program called EnergyPlus will be available in 1999 for Beta testing. It builds on the features of both DOE-2.2 and BLAST.

For additional information see DOE's Tool Directory at: www.eren.doe.gov/buildings/tools_directory
It is usually not wise to establish these numerical goals as absolute project criteria. The great variety of building types, programs, and conditions makes such rigid goals questionable and difficult to enforce. Nevertheless, incorporating this information into a programming document conveys the seriousness of energy consumption and the use of low energy as a design issue. By asking potential contractors to comment on this information in their proposal submissions, you can evaluate the energy responsiveness and insights of design contractors.

\section{Project Manager Checklist-}

Programming

- Has the goal to employ low-energy building design and other renewable energy strategies (such as daylighting and passive solar heating) whenever economically and technically feasible been stressed in program documents?

- Has achieving superior wholebuilding energy performance been highlighted as a written project goal?

- Have quantitative targets been established to help evaluate the energy implications of design decisions?

- Has the use of energy design tools and software been encouraged?

\section{Choosing Design Professionals}

Currently, there is a wide disparity in the energy sensitivity and interest among design professionals. Some architecture and engineering firms have a strong commitment to resource optimization and view it as a leading design consideration and directive. Others, while generally acknowledging that low energy consumption is a desirable end, do not see it as a central determinant of building form. They are usually content to postpone energy considerations to late in the design process when improvements are limited to 
alternative heating, ventilating, and air-conditioning (HVAC) and lighting selections. At that point in the process, major opportunities are likely to have been missed.

\section{Evaluate Commitment to Achieving Energy Performance}

To maximize energy performance, a supportive, knowledgeable architecture and engineering team must be selected. An architect unconcerned with energy performance coupled with an engineering firm with impeccable energy credentials is unlikely to produce an optimal building design. The reverse situation is also true. What is critical is the selection of a team that is prepared to work together to achieve superior building performance.

\section{Adopt Appropriate Solicitation Language}

During the selection process, successful architecture firms should enthusiastically respond to inquiries about energy consciousness. As part of their formal written and verbal presentations, they should address project-specific energy challenges and opportunities. The principal-in-charge and the project architect should demonstrate familiarity with critical concerns such as low-energy building design, daylighting, and peak demand. Successful candidates should clearly describe a design process in which the energy implications of design decisions will be evaluated at each phase with tools appropriate to that phase.

\section{Selecting Energy-Conscious Design} Professionals

The following language can be used to modify or supplement solicitations for design services:

- Successful applicants should state their commitment to whole-building performance and demonstrate their ability to respond to the energy targets set in program documents.
- Successful applicants should propose a team organization that encourages energy design quality and that can respond constructively to energy analysis results.

- Successful applicants should demonstrate a familiarity with new energy technologies such as highperformance glazings, lighting, and HVAC controls.

- Successful applicants should be able to cite completed projects that feature workable, cost-effective, energy-efficient, and low-energy design principles.

- For small projects (residences and commercial and institutional projects of less than about 20,000 $\mathrm{ft}^{2}$ ), successful applicants should demonstrate an understanding of daylighting and passive solar heating in cold climates and passive solar cooling in warm climates. For large projects (more than 20,000 $\mathrm{ft}^{2}$ ), successful applicants should demonstrate an understanding of daylighting, passive solar cooling, and sun control strategies.

- Successful applicants should demonstrate a familiarity with computer-based energy analysis techniques.

- Successful applicants should demonstrate an understanding of the most recent federal code, 10 Code of Federal Regulations (CFR) 435, or the comparable commercial code, American Society of Heating, Refrigerating, and AirConditioning Engineers (ASHRAE) energy standard, Standard 90.1.

\section{Choosing Appropriate Energy Analysis Techniques and Alternatives}

\section{Be Realistic}

Energy calculations, regardless of their sophistication, cannot precisely predict actual energy consumption. Factors such as construction quality, occupancy schedules, and maintenance procedures may vary markedly 
Table 1. Appropriate investments to be made in energy analysis and consulting services when designing a new building or making major renovations, by building size and energy-use intensity (per square foot of conditioned space).

\begin{tabular}{|c|c|c|c|}
\hline \multirow{2}{*}{ Energy Use Type } & \multicolumn{3}{|c|}{ Investment, \$/ft 2} \\
\cline { 2 - 4 } & $\begin{array}{c}\text { Small buildings } \\
\left(0 \text { to } 20,000 \mathrm{ft}^{2}\right)\end{array}$ & $\begin{array}{c}\text { Medium buildings } \\
(20,000 \text { to } \\
\left.100,000 \mathrm{ft}^{2}\right)\end{array}$ & $\begin{array}{c}\text { Large buildings } \\
\left(100,000 \mathrm{ft}^{2}\right. \\
\text { and above })\end{array}$ \\
\hline $\begin{array}{c}\text { Moderate Energy Users } \\
\text { including single-family } \\
\text { residences, housing, } \\
\text { and warehouses }\end{array}$ & $\$ 0.35$ to $\$ 0.25$ & $\$ 0.25$ to $\$ 0.15$ & $\$ 0.15$ to $\$ 0.05$ \\
\hline $\begin{array}{c}\text { High Energy Users } \\
\text { including offices, } \\
\text { factories, and service } \\
\text { centers }\end{array}$ & $\$ 0.40$ to $\$ 0.30$ & $\$ 0.30$ to $\$ 0.20$ & $\$ 0.20$ to $\$ 0.10$ \\
\hline $\begin{array}{c}\text { Very High Energy Users } \\
\text { including laboratories } \\
\text { and hospitals }\end{array}$ & $\$ 0.45$ to $\$ 0.35$ & $\$ 0.35$ to $\$ 0.25$ & $\$ 0.25$ to $\$ 0.15$ \\
\hline
\end{tabular}

Note: This table adjusts the rule of thumb for building size and energy use characteristics and provides a more precise guideline. Note that as buildings get larger there is an economy of scale so it is not necessary to expend as much on a square-foot basis. cost of energy consulting and analysis services that a project can support. It is equally important to be realistic about the extent of the benefits that can be expected as a result of applying these services. This is true whether the analysis is being conducted internally or by outside contractors or consultants.

As a rule of thumb, Federal building managers should be willing to spend as much as 1 year's expected energy savings for new building energy analysis studies. ${ }^{1}$ For major renovations that include window replacements, insulation retrofits, and lighting changes, this rule of thumb is also valid. For minor renovations involving only component changes such as fixture or ballast replacements, it is prudent to limit expenditures to not more than half the values recorded in Table 1.

\section{Establish a Base Case}

Related to the issue of what you should be prepared to spend for energy consulting or extended professional services is the issue of establishing an appropriate base-case building definition to evaluate lowenergy design investments during the design process. Establishing a viable base case is also an essential step when pursuing a performance compliance path under 10 CFR 435 or the comparable commercial code, ASHRAE 90.1.

This task can be deceptively difficult because there is no universal approach. Early in the design process it may be the minimum, codecomplying structure and a generic "shoebox" form. Later it may be a building design that has already been partially optimized and in the shape of the actual building design, but

ings, cost-effectiveness is defined in 10 CFR 436 as a savings-to-investment ratio of greater than 1.0 during a 40-year analysis period for building envelope measures and a 25-year analysis period for equipment measures. This means that it is important to be practical about the extent and
${ }^{1}$ Like all rules of thumb, this recommendation must be tempered with common sense and an appreciation of special conditions. In some instances, such as demonstration projects or projects with high energy consumption rates, investing 2 to 3 years' worth of savings for energy consulting services can be justified. 
with different subsystems. How much time and money are you prepared to spend to analyze this nonexistent, and never-to-be-built, baseline structure?

These decisions will go a long way in deciding what energy-based interventions will prove cost effective. Consequently, establishing the specifications of an appropriate basecase building design is an important task that the project manager and design professional or energy consultant should clarify early in the design process.

It is often necessary to define a base-case building during programming to establish aggressive energy performance targets. If this is so, you will probably want to retain this basecase definition throughout the project.

\section{What Can I Expect for My Money?}

There is a clear relationship between what energy analysis you can afford and what deliverables and level of detail you can expect from the analysis. Although schematic, the following list can help you understand what level of effort you can expect from your energy design professional or your energy consultant.

Modest Effort: 3 to 15 person days (less than $\$ 10,000$ )

At this level, your contractor or consultant might be expected to:

- Attend a preliminary meeting and present results at a second meeting

- Help define energy targets (in both dollars and Btus per square foot) during programming by running a design-phase analysis tool such as Energy-10 or Energy Scheming

- Together with the project architect or manager, use similar tools to study schematic building envelope and massing alternatives, including such options as daylighting, night cooling, passive solar heating, and glazing optimization during the early phases of design

- Be available to the project architect or manager throughout the design process to answer questions
- In one- or two-zone buildings, analyze a limited number of simplified HVAC configurations

- Provide a brief, written final report summarizing recommendations.

Intermediate Effort: 3 to 12 person weeks (between $\$ 10,000$ and $\$ 40,000$ )

At this level, your contractor or consultant might be expected to:

- Attend regular meetings during the design and design development phases

- Help define energy targets (in both dollars and Btus per square foot) during programming

- Together with the project architect or manager, run DOE 2.1E, Blast, or the equivalent hour-by-hour simulation tool to study schematic building envelope and massing alternatives, including such options as daylighting, shading, lighting controls, and glazing optimization during the early phases of design

- Be available to the project architect or manager throughout the design process to answer questions

- Analyze a significant number of alternative HVAC configurations, including controls and distribution options, during design development

- Conduct an economic analysis of building design and systems alternatives, including life-cycle costs or discounted paybacks

- Provide a comprehensive, written final report summarizing recommendations.

Large Effort: 2 to 6 person months (more than \$40,000)

At this level, your contractor or consultant might be expected to:

- Attend regular meetings throughout the project

- Help define energy targets (in both dollars and Btus per square foot) during programming

- Together with the project architect or manager, run DOE 2.1E, Blast, or the equivalent hour-by-hour simulation tool to study schematic 
building envelope and massing alternatives, including such options as daylighting, shading, lighting controls, and glazing optimization during the early phases of design

- Be available to the project architect or manager throughout the design process to answer questions

- Maintain an ongoing energy analysis of the evolving design to inform the designers of the energy implications of design alternatives

- Analyze a significant number of alternative HVAC configurations, including controls and distribution options

- Conduct a comprehensive economic analysis of building design and systems alternatives, including life-cycle costs or discounted paybacks (Many Federal agencies require that at least three alternative HVAC systems be analyzed on a life-cycle basis.)

- In some cases, help write or compile a building commissioning handbook

- In the case of major renovation projects, conduct physical tests of existing conditions such as infiltration studies, thermography, and equipment efficiency studies

- Undertake higher-order prediction studies such as physical daylight study models of prototypical office spaces or computational fluid dynamic models of convective flows in atriums

- Team with the utility to analyze utility interface issues such as off-peak ice thermal storage and other peak-shaving and peakshifting strategies

- Monitor actual building performance

- Produce comprehensive final and intermediate reports, as appropriate.
Which Energy Analysis Technique Should I Use?

\section{Clarify Tasks}

As the lists suggest, there are many kinds of analysis techniques. These include calculations (such as loads or energy consumption programs), physical and computer modeling (such as daylight study models or light-tracing simulations), and testing (such as infiltration or HVAC equipment efficiency studies). Individual projects can benefit from some or all of these studies.

The most common forms of analysis procedures involve calculations. Although hand-based methods remain valid and can be used, today most designers and consultants use computer-based methods. These software programs have varying levels of accuracy, are intended to be used at different phases of design, and require very different levels of effort and cost. As a Federal manager, your goal should be to match an appropriate level of analysis to the task at hand.

For example, some tools, such as Energy-10 or the Windows version of DOE 2, Blast, and other programs, have been designed (or, are being designed) to provide immediate feedback to the designer or project manager during the earliest phases of a project. Others, such as DOE 2.1E and Blast, require more input time and detail. Consequently, they are generally reserved for later in the design process when many architectural decisions have already been finalized. Still other software packages, such as the proprietary program Trace, have been developed to assist mechanical equipment selection and are often distributed by manufacturers. They are generally used only after all building envelope and massing decisions have been finalized. 


\section{Basic Calculation Methodologies}

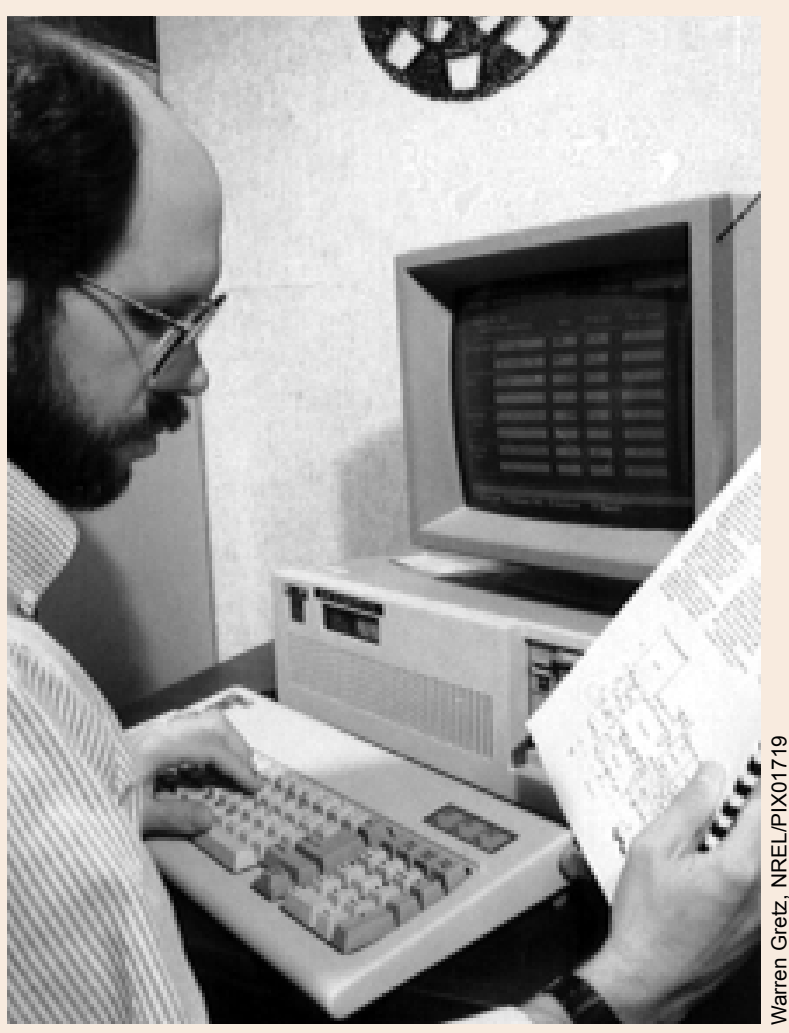

A variety of software packages are available for generating energy consumption estimates.
Most energy programs use one of these underlying calculation procedures.

Correlations. In a correlation-based program, daily, monthly, or seasonal building performance is computed by comparing, or correlating, the performance of the building in question against predetermined equations (or curves) that predict the performance of the building based on key thermal characteristics and climate information. Correlation programs generally run quickly because they demand a minimum of computation, but this speed is at the expense of some accuracy. Also, because of their relative simplicity, correlation programs are not able to evaluate the important trade-offs between certain interactive energy strategies such as daylighting and heating or thermal mass and cooling.

Simulations. By far, the most precise and computationally intensive approach to energy performance calculations is hourby-hour simulations. In this approach, building energy requirements are calculated based on "first principles" on an iterative basis each hour of the year. This approach allows the integrated effect of building design decisions such as daylighting, glazing selection, shading devices, and lighting controls to be most accurately modeled.

Even a few years ago, analyzing a building using hour-by-hour simulation software required considerable run times. Today, new generations of powerful personal computers permit annual results in minutes or even seconds.

\section{Match Tool to Task}

Calculations are made of building energy performance for two primary reasons. Either they are made to size mechanical equipment or to predict the annual energy consumption of a structure. Although these two tasks are not mutually exclusive and some programs can handle both tasks, they do tend to be conducted in isolation from each other. Any energy analysis should determine both peak loads (sizing requirements) and annual energy consumption.

Sizing programs are primarily geared to calculating peak hourly load conditions independently during the heating season and during the cooling season for the purposes of sizing mechanical equipment. Almost all buildings have a sizing analysis of some kind run by an architect, engineer, or mechanical contractor in order to select the equipment. Most sizing programs are based on consensus procedures and algorithms established by ASHRAE, but many are proprietary products distributed or sold by equipment manufacturers. ${ }^{2}$

Annual consumption programs are primarily designed to analyze the total energy consumed by a structure in a typical year expressed in terms of Btus, dollars, or pollution avoidance. To achieve this end, the most accurate of these software packages calculate building loads on an hourly basis and then assume a mechanical system of some defined efficiency and control strategy is used by the structure to meet this hourly load. Based on the inefficiencies of the mechanical system and the distribution system of the building (e.g., ductwork losses), 


\begin{tabular}{|c|c|c|c|c|}
\hline $\begin{array}{l}\text { Calculate } \\
\text { loads }\end{array}$ & $\begin{array}{l}\text { Select } \\
\text { HVAC } \\
\text { system }\end{array}$ & $\begin{array}{c}\text { Calculate } \\
\text { energy } \\
\text { consumption }\end{array}$ & $\begin{array}{c}\text { Input utility } \\
\text { and energy } \\
\text { rates }\end{array}$ & $\begin{array}{c}\text { Calculate } \\
\text { energy } \\
\text { costs }\end{array}$ \\
\hline
\end{tabular}

Figure 2. This flowchart can be used to determine energy costs.

the program can then make an estimate of building energy consumption for that hour. Annual performance is calculated by summing the hourly results for all 8,760 hours of the year.

In many cases, annual energy consumption programs include provisions for inputting utility rate structures so that annual energy cost values (not only Btu consumption values) can be determined. Figure 2 indicates the general steps that must be followed to fully evaluate project energy consumption costs.

Who Should Perform the Analysis?

Energy analyses can be performed in-house or out-of-house; they can be run by your primary design contractors (if they have adequate energy expertise) or by energy consultants. The most important thing to remember when performing an energy analysis is that the results must be taken seriously and be given sufficient weight in the course of the design.

Project Manager ChecklistDetermining Energy Analysis Techniques

- Is there a match between project phase and design tool?

- Has a reasonable budget for project energy analysis and consulting services been established based on Table 1?
- Is there a reasonable correlation between potential energy savings and investment in energy analysis and consulting services?

- Have you ensured that the information generated from quantitative energy analyses will have an impact on the design process?

- How will the cost-effectiveness of energy investments be determined?

\section{Conclusion}

A low-energy building is not simply the product of new hardware; it is the product of better design. Creating a low-energy building requires comprehensive attention to detail throughout the design process. Even after the building is constructed and properly commissioned, effective post-occupancy analysis is necessary to ensure that the anticipated performance has been achieved.

Studies show that buildings designed from inception with energy consumption in mind by knowledgeable design teams do significantly outperform the average. So, get involved and take a proactive stance. The directives and criteria you set early in the programming and project development phase will have a crucial impact on any building's energy effectiveness.

\footnotetext{
2 Some sizing programs also provide an estimate of annual energy consumption. In many cases, however, this calculation is based on simplified algorithms using correlations or temperature bins.
} 


\section{Glossary}

ADELINE (includes SUPERLITE and RADIANCE) - A software tool for daylighting design that links daylighting and thermal performance.

algorithm - A step-by-step procedure for solving a problem or accomplishing some end; the underlying equations that govern a calculation procedure.

annual consumption energy - The actual energy consumed by a building in 1 year-compare with "load."

ASEAM - A simplified energy analysis software tool based on the bin method of calculating annual performance. It is not geared to properly evaluate the interactive effect of many passive solar features such as daylighting and thermal mass.

bins - Groupings of temperature, usually in $5^{\circ} \mathrm{F}$ increments centered on a reference value. For example, the $62^{\circ}$ temperature bin for a particular climate represents the number of hours during the year when temperatures fall between $59.5^{\circ}$ and $64.5^{\circ} \mathrm{F}$.

BLAST - A detailed, annual energy performance software tool that is able to model the interactive effects of passive solar design strategies such as daylighting, passive solar heating, and thermal mass.

correlation - An analysis technique whereby building energy performance is calculated by comparing, or correlating, the performance of the building in question with prevalidated equations (or curves) based on key thermal characteristics and climate information.

daylighting - The intentional, controlled use of natural light to reduce the requirement for artificial lighting in a building.

DOE 2.2 - An energy analysis software program that calculates the hourby-hour energy use of a building given detailed information on the building's location, construction, operation, and heating, ventilating, and air-conditioning systems. It was developed by Lawrence Berkeley National Laboratory in collaboration with Los Alamos National Laboratory and supported by the U.S.

Department of Energy.

elimination parametrics - An analysis procedure that involves the zeroing out of individual load components, such as artificial lighting, for the purpose of evaluating the consequence of that component on total building loads or energy consumption.

Designing Low Energy Buildings with ENERGY-10 Software - An hour-byhour, annual simulation program designed for the analysis of residential and commercial buildings of less than approximately $10,000 \mathrm{ft}^{2}$ (or two zones). It was specifically conceived to be used during the earliest phases of design. It was developed by the National Renewable Energy Laboratory with support from the U.S. Department of Energy.

hour-by-hour simulation - An analysis approach that calculates the energy loads and consumption of a building for each hour of the year. Examples of hour-by-hour simulation software include DOE 2.2 and ENERGY-10.

load - The net hourly heat loss or heat gain from a structure that must be met by a heating system to achieve interior comfort conditions.

passive solar design - A whole-building, integrated approach to energy design that minimizes loads and uses standard elements of a building, such as windows, walls, and floors, to collect, store, and release the sun's energy for heating, cooling, and lighting.

Trace - A proprietary equipment-sizing program developed by the Trane Corporation. 
FEMP gratefully acknowledges the major contribution to this guide from Donald Prowler, FAIA, President of Donald Prowler \& Associates.

PSIC also provides courses on designing low-energy buildings and design assistance for new construction in support of FEMP. For more information contact your FEMP regional representative.

\section{Sharon Gill (Chicago) \\ Midwest Region \\ 312-886-8573}

Bill Klebous (New York)

Mid-Atlantic Region

212-264-0691

Leah Boggs (Philadelphia)

Mid-Atlantic Region

215-656-6976

Arun Jhaveri (Seattle)

Western Region

206-553-2152

Randy Jones (Denver)

Central Region

303-275-4814

Paul King (Boston)

Northeast Region

617-565-9712

Doug Culbreth (Raleigh, N.C.)

Southeast Region

919-782-5238

David Waldrop (Atlanta)

Southeast Region

404-347-3483
You can also contact:

Helen English

Passive Solar Industries Council

1331 H Street, N.W., Suite 1000

Washington, DC 20005

Phone: 202-628-7400

Fax: 202-393-5043

E-Mail: PSICouncil@aol.com

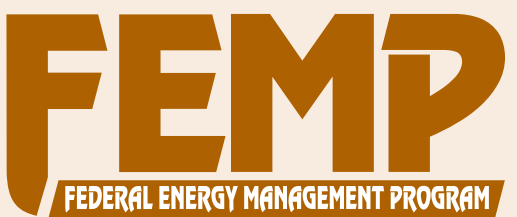

Federal building design assistance is provided through the following national laboratories in support of the U.S. Department of Energy Federal Energy Management Program (FEMP).

\section{Laboratory Contacts Include:}

National Renewable Energy Laboratory, Andy Walker, 303-384-7531

Lawrence Berkeley National Laboratory, Rick Diamond, 510-486-4459

Pacific Northwest National Laboratory, Steve Parker, 509-375-6366

\section{For More Information Contact:}

Anne Sprunt Crawley

Team Leader, Technical Assistance

DOE FEMP, 202-586-1505

FEMP Help Desk:

1-800-DOE-EREC (363-3732)

Internet: http://www.eren.doe.gov/femp
NOTICE: This report was prepared as an account of work sponsored by an agency of the United States government. Neither the United States government nor any agency thereof, nor any of their employees, makes any warranty, express or implied, or assumes any legal liability or responsibility for the accuracy, completeness, or usefulness of any information, apparatus, product, or process disclosed, or represents that its use would not infringe privately owned rights. Reference herein to any specific commercial product, process, or service by trade name, trademark, manufacturer, or otherwise does not necessarily constitute or imply its endorsement, recommendation, or favoring by the United States government or any agency thereof. The views and opinions of authors expressed herein do not necessarily state or reflect those of the United States government or any agency thereof.

Printed in the United States of America

Available to DOE and DOE contractors from:

Office of Scientific and Technical Information (OSTI)

P.O. Box 62

Oak Ridge, TN 37831

Prices available by calling 423-576-8401

Available to the public from:

National Technical Information Service (NTIS)

U.S. Department of Commerce

5285 Port Royal Road

Springfield, VA 22161

703-605-6000 or 800-553-6847

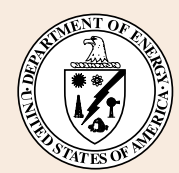

Produced for the U.S. Department of Energy (DOE) by the National Renewable Energy Laboratory, a DOE national laboratory

DOE/GO-10099-723

March 1999 